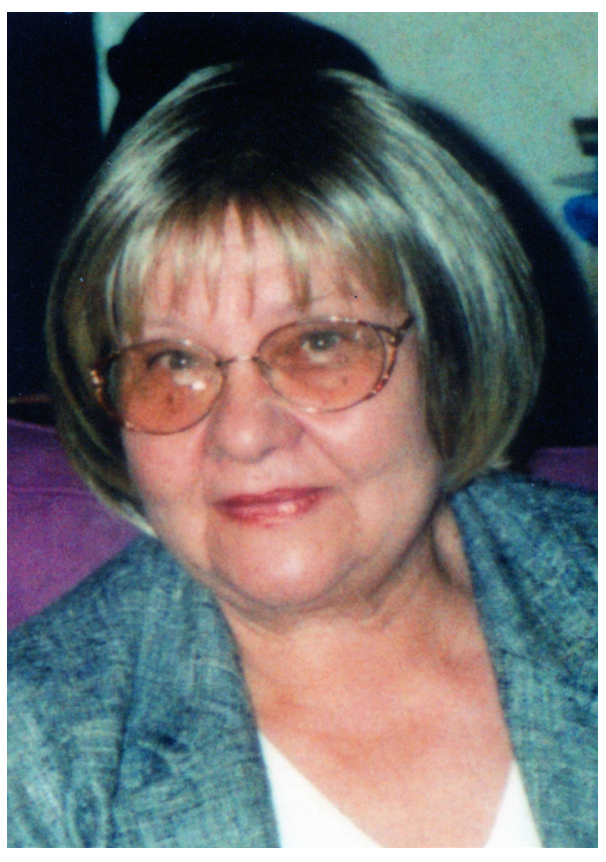

Памяти македонского популяризатора русской литературы и культуры Тани Урошевич (1936-2020)

\title{
In Memory of Macedonian Popularizer of Russian Literature and Culture Tanja Urošević (1936-2020)
}

10 марта 2020 г. не стало выдающегося популяризатора и переводчика русской литературы, талантливой македонской писательницы Тани Урошевич. Благодаря ее таланту и самоотверженному многолетнему труду зазвучали на македонском языке голоса многих классиков русской литературы. В течение нескольких десятилетий именно она была основным посредником между культурами двух славянских народов, что сама переводчица воспринимала как особую миссию, возложенную на нее судьбой. Рожденная в семье русских эмигрантов, блестяще владеющая русским языком, она олицетворяла часть русского мира, сохраненного в изгнании русскими беженцами, которые в 1920-е гг. осели в Королевстве Югославия, в том числе в Скопье. В то же время она глубоко чувствовала выразательные возможности и специфическую образность родного македонского языка, обладая глубокими профессиональными знаниями. Выпускница кафедры истории югославских литератур филологического факультета Университета им. Свв. Кирилла и Мефодия в Скопье, она раскрыла свое дарование при переводе вершинных произведений русской литературы, требующих всесторонних и глубоких знаний в области истории и культуры и тонкого чувства индивидуального стиля писателя. Этому труду она посвятила всю свою жизнь. С 1960-х гг. в ее переводах македонские читатели знакомились с произведениями А. Пушкина, Н. Гоголя, Л. Толстого. Среди переведенных книг также «Идиот» Ф. Достоевского, «Деревня» И. Бунина, «Мастер и Маргарита» и «Театральный роман» М. Булгакова, «Доктор Живаго» Б. Пастернака, «Дар» В. Набокова, «Русский лес» Л. Леонова и др. К длинному списку можно добавить «Письма Борису Пастернаку» М. Цветаевой, антологии рассказов «Дьяволиада» и «Хрустальный свет», поэтический сборник «Двенадцать русских поэтов» и др.

Перевод «Мастера и Маргариты» (1970) сыграл особую роль в развитии македонской литературы, продемонстрировав ее готовность к восприятию этого многослойного и весьма насыщенного текста. Он был выполнен Таней Урошевич в кратчайший срок с журнального издания романа М. Булгакова. Вместе с переводами на сербский, хорватский и словенский языки он положил начало триумфальному шествию русского классика в Югославии и открыл новую страницу в восприятии русской литературы XX в. в Македонии. Перевод на македонский 
язык был первым шагом к включению романа Булгакова в национальное художественное сознание, положил начало процессу превращения творчества писателя в неотъемлемую часть национальной культуры. Не будет преувеличением сказать, что перевод Тани Урошевич внес решающий вклад в формирование «культа» Булгакова в Македонии. Не менее значимым для национальной литературы был и ее перевод романа Б. Пастернака.

«Русская тема» стала важнейшей частью и собственного творчества Тани Урошевич. Жизнь русских эмигрантов в межвоенной Македонии и их потомков после войны стала основой сюжета ее романа «Аквамарин» (2004) и связующим мотивом сборника рассказов «Красные бусы, магнетический перстень» (2009). Они представляют собой художественное осмысление сложившейся в 1920-1930-е гг. в Македонии русской культурной среды. Основу сюжета последнего романа писательницы «Ура, Арал!» (2019) составляют впечатления от поездки в Россию и Узбекистан в начале 1990-х гг.

Вступив на писательскую стезю в зрелом возрасте, Таня Урошевич сразу привлекла к себе внимание высоким художественным уровнем произведений, повествовательной культурой текста, продемонстрировала богатство и разнообразие творческих интересов и быстро заняла важное место в современной македонской литературе (наряду с упомянутыми, это романы «Оплошность», 2008; «Три новеллы», 2017). Интересный эксперимент был воплощен в сборнике «Обмен посланиями» (2013), написанном совместно с писателем и супругом Владой Урошевичем, где один и тот же мотив реализован в двух вариантах, представляющих «женское» и «мужское» видение реальности.

Кончина выдающего представителя национальной культуры и литературы - тяжелая утрата для всех нас. Редакция приносит свои соболезнования семье, близким, здрузьям и коллегам Тани Урошевич.

Светлая ей память.

А.Г. Шешкен

Сведения об авторе:

Алла Геннадьевна Шешкен,

доктор филол. наук

профессор

филологический факультет

МГУ имени М.В. Ломоносова
Alla Sheshken,

Doctor of Philology

Professor

Philological Faculty

Lomonosov Moscow State University

sheshken@yandex.ru 